\title{
El amor es para siempre
}

Muy pocas veces en la historia del cine se han presentado casos de relaciones de afecto que duren para siempre, mucho menos: entre realizadores. Sí se ha presentado entre el creador y su musa (lo de Federico Fellini y Giulieta Massina es cosa seria) o inclusive : entre actores (por supuesto, no es el caso de Brad Pitt). Pero que dos directores de cine decidan unir sus vidas es realmente digno : de mención. Pasó entre una belga que nos abandonó hace poco, chiquita pero muy vivaz y coqueta, y un director que bebió de los referentes clásicos de Hollywood para rubricar uno de los mejores musicales de la historia. Agnès Varda y Jacques Demy se prodigaron respeto, cariño y amor mientras estuvieron juntos, hasta que : una terrible enfermedad se apoderó de Jacques y se lo llevó en 1990. Desde ese momento, Varda vivió el luto pero nunca dejó de rendir homenaje, recordar y proteger el legado de su esposo. Por : eso la presente edición de CineScrúpulos se dedica a revisar la: obra completa de ambos.

Justamente, a propósito de la construcción desde la mirada de la mujer, se traza también una comparación entre el cine de Claire Denis y el de Isabel Coixet para determinar si la configuración de sus personajes femeninos es similar o no. Como en la naturale- : za hay un equilibrio entre ambos géneros, hacemos algo parecido con el legado de Batman y nos preguntamos si las claves que : Adam West impregnó al personaje en la famosa serie de televisión de los años sesenta se encuentran en las propuestas cinematográficas que trasladaron a la pantalla Tim Burton y Joel Schumacher.

En otros terrenos audiovisuales, la cancelación de la extraordina- : ria serie Happy! ha dejado a muchos con los crespos hechos (nos : incluimos) y a modo de reivindicación se traza una aproximación desde la aparente influencia que tendría el cine de Danny Boyle : en las aventuras de Nick Sax y de su unicornio azul (no hablamos: de la canción de Silvio Rodríguez). Para mantener la cuota transgresora, se analizan también las películas de Ben Stiller a la luz : de lo desarrollado por esos especialistas de la comedia absurda y de la parodia que son el trío maravilla conformado por Jim : Abrahams, David Zucker y Jerry Zucker. Finalmente, la biografía : de Martin Scorsese sirve como punto de partida para determinar : cómo perfila el director neoyorquino el mundo criminal nortea- : mericano en sus películas.

No queremos terminar esta presentación sin dar la bienvenida al equipo completo de profesores de Historia del Cine de la UPC, quienes desde la presente edición forman parte del comité edito- : rial de CineScrúpulos. 